\title{
Роль аутофрагии в преждевременном старении клеток НМРЛ, индуцированном окислительным стрессом
}

\author{
(C) С.Е. Храпов, 3.И. Абрамова* \\ Казанский (Приволжский) федеральный университет \\ Россия, Республика Татарстан, 420008 г. Казань, улица Кремлевская, 18 \\ *Email: ziabramova@mail.ru
}

Установлено, что изменение уровня аутофрагии в клетках НМРЛ, связано с окислительным стрессом.

Ключевые слова: аутофагия, окислительный стресс, старение, немелкоклеточный рак легкого.

\begin{abstract}
Увеличение продолжительности жизни человека предполагает активное долголетие. Прогресс геронтологии привел к тому, что ожидаемая продолжительность жизни увеличилась за последние пятьдесят лет с 57,4 лет (1968г.) до 72,6 (2018г.) лет [1], но проблема долголетия все еще актуальна, т.к. связана с развитием патологических процессов. Одна из популярнейших теорий старения - теория свободных радикалов. Согласно этой теории, под действием внешних фракторов происходит утечка активных форм кислорода (АФК), и вместо выполнения обычных функций, они реагируют с макромолекулами, повреждая их. Так могут возникать мутации в ДНК и РНК, повреждаться мембрана, за счет реакций с липидами, нарушаться конформация белков. В клетках существуют молекулы-антиоксиданты, предотвращающие такие повреждения, путем устранения АФК, например супероксиддисмутазы, каталазы и т.д., но при избытке АФК или недостатке антиоксидантов возникает окислительный стресс - превышение продукции активных форм кислорода и азота над их инактивацией антиоксидантами. Эта теория объясняет не только старение, но и множество патологических процессов связанных со старением, например опухолевая трансформация [2]. Окислительный стресс - серьезное испытание для клетки: молекулы антиоксиданты уже не справляются с АФК, а последние наносят все больший урон не только макромолекулам в цитоплазме, но и органеллам, повреждая их. Для того, чтобы не допустить не поправимого, в клетке существуют механизмы программируемой клеточной гибели: апоптоза (ПКГ । типа) и аутофрагии ПКГ II типа). Согласно исследованиям [3,4,5], аутофрагия и АФК принимают участие в одних и тех же процессах, например при гипоксии, реоксидации, голодании, это в свою очередь позволяет предположить, что АФК являются молекуламииндукторами аутофагии.
\end{abstract}

Целью работы является оценка роли аутофагии в преждевременном старении в опухолевых клетках немелкоклеточного рака лѐгкого (НМРЛ). Для достижения цели поставлены следующие задачи: (1) Установить уровень АФК в клетках НМРЛ в динамике после добавления $\mathrm{H}_{2} \mathrm{O}_{2}$ методом окрашивания дигидрородамином 123; (2) Установить уровень апоптоза и некроза в культуре клеток НМРЛ в динамике; (3) Установить изменение уровня аутофагии в клетках НМРЛ, вызванного окислительным стрессом.

В качестве модели НМРЛ использовали культуру клеток А549. Клетки делили на три группы, состояние которых определяли через $0,24,48$ часов после добавления $\mathrm{H}_{2} \mathrm{O}_{2}$. По истечении времени, в две лунки добавляли дигидрородамин 123 (Thermo Fisher 
Scientific (USA)), лунки инкубировали в темноте 60 мин при $37^{\circ} \mathrm{C}$ в присутствии $5 \% \mathrm{CO}_{2}$, затем обрабатывали трипсином и промывали. Для анализа уровня аутофагии и апоптоза использовали Autophagy Assay Kit - ab139484 Annexin V-FITC Apoptosis Staining / Detection Kit - ab14085(Abcam plc, UK). Образцы анализировали на приборе FACSCalibur. Полученные результаты обрабатывали в программе FlowJo X.

В результате при анализе уровня АФК в клетках А549 установили, что через 24 часа после добавления в питательную среду $\mathrm{H}_{2} \mathrm{O}_{2}$ уровень АФК в клетках снижается, о чем свидетельствует изменение уровня фрлуоресценции (с 147 у.е. до 54 у.е.) на фоне снижения количества клеток, примерно, на 25\% (рис.1, зеленый пик). Через 48 часов количество клеток с таким же уровнем АФК увеличивается на $10 \%$ (рис.1, оранжевый пик).

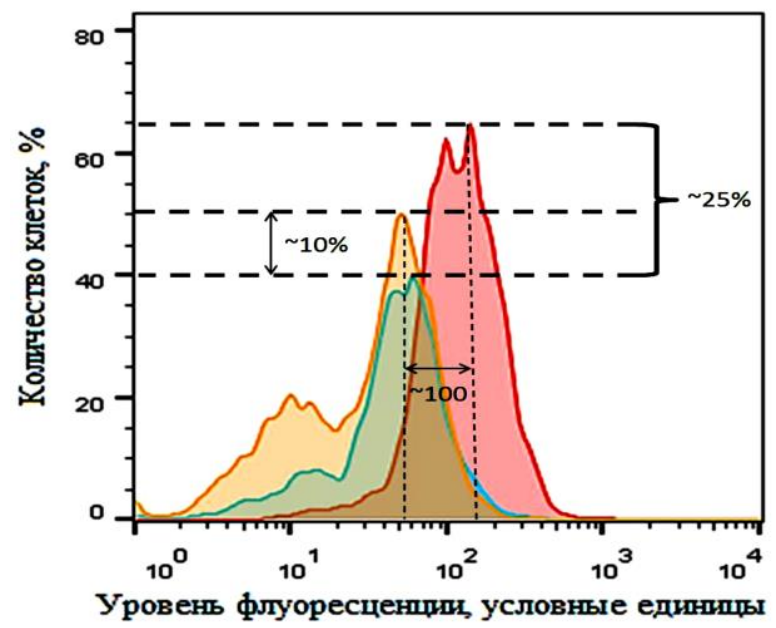

Рис.1. Анализ уровня АФК в свежевыделенных клетках (красный пик), через 24ч (зелены й пик) и 48 ч (оранжевый пик) культивирования.

Для того чтобы определить с чем связаны изменения количества клеток в процессе культивирования, мы определяли форму клеточной гибели.

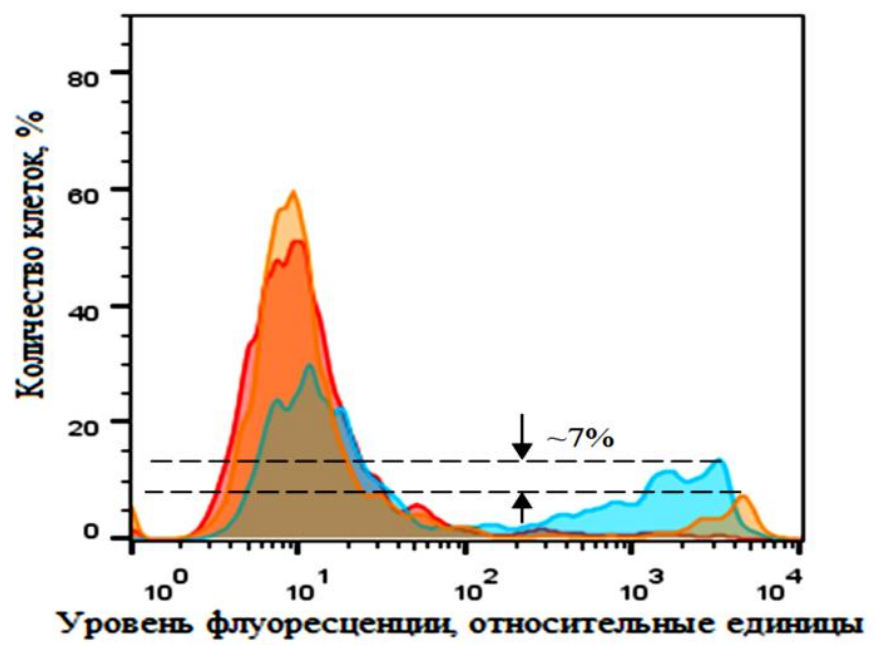


Рис.2. Анализ изменения уровня некротических клеток в процессе культивирования через 24 ч (синий пик) и 48 ч (оранжевый пик) культивирования. Уровень интенсивности некроза в клетках оценивали по уровню интенсивности фрлуоресценции.

Клетки на стадии апоптоза практически отсутствовали. Оценка уровня клеток на стадии некроза (рис. 2) показала, что через 24 часа уровень некротических клеток составлял 14\% (рис.2, синий пик) и снизился до 7\% через 48 час культивирования (рис.2 оранжевый пик). Эти результаты позволяют предположить, что мы получили состарившуюся культуру клеток.

При оценке клеток на стадии аутофагии мы показали, что активность аутофагии повышается. Как следует из рис. 3 в образце клеток до культивирования после добавления $\mathrm{H}_{2} \mathrm{O}_{2}$ можно выделить две популяции клеток: большинство клеток с достаточно низкой интенсивностью аутофрагии (около 50\%) и с высоким уровнем активности аутофагии (около 17\%). Через 24 часа культивирования количество клеток с повышенной интенсивностью аутофагии превысило 65\% и снизилось до $40 \%$ через 48 часов культивирования.

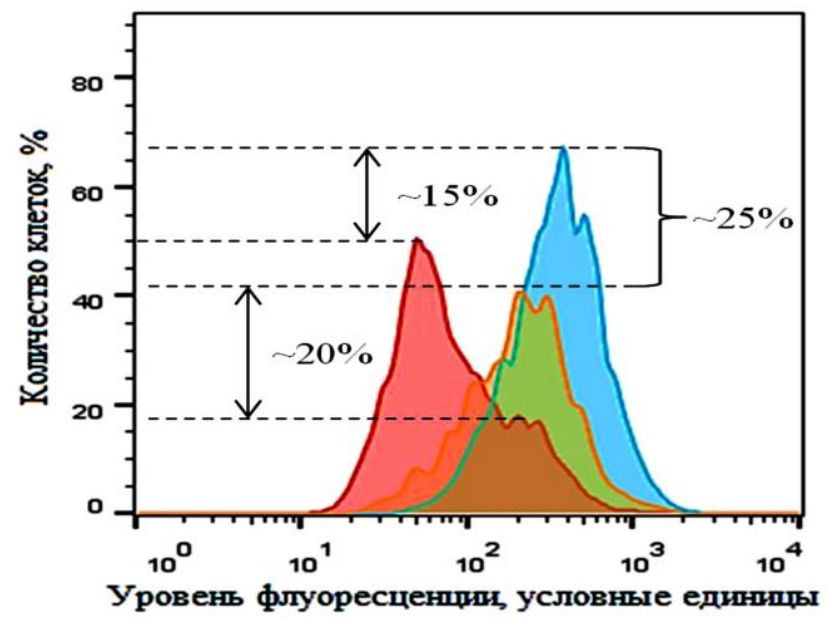

Рис. 3. Оценка уровня количества клеток и уровня экспрессии аутофагии в культуре до культивирования (красный пик). через 24 ч (синий пик) и 48 ч (оранжевый пик) культивирования.

Уровень АФК снижался на фоне увеличения интенсивности аутофагии, т.е. можно предположить, что АФК участвуют в индукции аутофагии в клетках. В своей работе авторы [5] также пишут, что АФК являются эффрективными индукторами аутофагии. Кроме того с учетом данных литературы и наших данных, можно предположить, что старение опухолевых клеток приводит к нарушениям самого процесса аутофагии (ПКГ ІІтипа), и как следствие нарушению клиренса опухолевых клеток, что возможно, приводит к развитию патологического процесса за счет увеличения аутоантигенов при гибели опухолевых клеток путем некроза. 


\section{Литература}

1. Life expectancy at birth, total (years). The World Bank Group // World Bank Group $\begin{array}{llllll}\text { [Electronic } & \text { resource]. } & - & 2018 . & \text { URL: }\end{array}$ https://data. worldbank.org/indicator/SP.DYN.LE00.IN?end=2018\&start=1960 - Accessed: 20.03.2021.

2. Мелихова Л.В., Чентиева Л.А., Лущик М.В. Основные теории старения //Международный студенческий научный вестник. 2016. Т. 4. С. 156-157.

3. Filomeni G., De Zio D., Cecconi F. Oxidative stress and autophagy: the clash between damage and metabolic needs //Cell Death and Differentiation . 2015. V. 22. P. 377388.

4. Новиков В.Е., Левченкова О.С., Пожилова Е.В. Роль активных форм кислорода в физиологии и патологии клетки и их фрармакологическая регуляция // Обзоры по клинической фрармакологии и лекарственной терапии. 2014. Т. 12. С. 13-21.

5. Зенков Н.К., Чечушков А.В., Кожин П.М., Мартинович Г.Г., Кандалинцева Н.В., Меньщикова Е.Б. Аутофрагия как механизм защиты при окислительном стрессе //Бюллетень сибирской мдицины. 2019.Т. 18. С. 195-214.

\section{The role of autophagy in premature aging of NSCLC cells induced by oxidative stress}

S. E. Khrapov, Z. I. Abramova *

Kazan (Volga Region) Federal University

Russia, Republic of Tatarstan, 420008 Kazan, Kremlevskaya street, 18

*Email: ziabramova@mail.ru

It was found that changes in the level of autophagy in NSCLC cells are associated with oxidative stress.

Key words: autophagy, oxidative stress, aging, non-small cell lung cancer. 